\title{
Phase transitions of samani date palm (Phoenix dactylifera L.) fruit using differential scanning calorimeter (DSC)
}

\author{
Amr M. Zaitoon ${ }^{1 *}$, Atef M. Elansari', Yehia S. Ahmed ${ }^{2}$, Nahla A. Taha ${ }^{3}$ \\ ${ }^{1}$ Department of Agricultural and Bio-systems Engineering, Faculty of Agriculture, Alexandria University, Egypt, ${ }^{2}$ Department of Pomology, \\ Faculty of Agriculture, Alexandria University, Egypt, ${ }^{3}$ Department of Fabrication Technology Research, STRA-City, Egypt
}

\section{A B S T R A C T}

\begin{abstract}
The determination of the phase transitions of date using Differential Scanning Calorimeter (DSC) depends on two factors: 1) instrumental factors such as heating rate and annealing condition and 2) sample characteristics such as moisture content. This study investigated the effect of these factors on the glass transition temperatures $\left(T_{g}\right)$ and other thermal properties of Samani dates. Three different heating rates; 1,5 , and $10^{\circ} \mathrm{C} / \mathrm{min}$ were employed during DSC scan to study its effect on the thermal transitions of dates. In addition, samples were annealed for $30 \mathrm{~min}$ at $-30^{\circ} \mathrm{C}$ to study the effect of annealing on the same properties. Different levels of moisture content were also used to study its impact on the same properties. When heating rate increased from 1 to $10^{\circ} \mathrm{C} / \mathrm{min}, \mathrm{T}_{\mathrm{g}}$ increased from- 41.58 to- $39.31^{\circ} \mathrm{C}$. Also, $\mathrm{T}_{\mathrm{g}}$ decreased significantly from -41.95 to $-53.64^{\circ} \mathrm{C}$ as moisture content of date increased from 30.4 to $51.2 \%$, respectively. These results can be used to enhance stability of stored dates, thus extend its shelf-life. The procedures developed can establish a protocol to yield phase transitions information for dates using DSC.
\end{abstract}

Keywords: Dates, DSC, Glass Transition, Thermal Properties

\section{INTRODUCTION}

Date palm (Phoenix dactylifera L.,) fruits have a major role in the social life of communities in North Africa and the Middle East (Ateeq et al., 2013). The date palm tree and its fruit have numerous horticultural, nutritional, medicinal, architectural, environmental uses (Siddiq et al., 2014). The maturity stages of dates can be classified according to their physiological development into three stages; khalal, rutab and tamr (Manickavasagan et al., 2014). Dates are a basic dietary component for people living in many Arab countries (Haider et al., 2014) and are considered a complete diet (Biglari, 2009). Dates are rich with sugar, minerals, and vitamins (Al-Khayri and Ibraheem, 2014). It exhibits various useful properties such as antioxidant, antifungal, antihyperlidimic activity and hepatoprotective activity (Ismail and Radzi, 2013). In 2013, the world production of dates was about 7,627,624.40 tons and the top five producing countries were Egypt, Iran, Saudi Arabia, Algeria, and Iraq (FAOSTAT data, 2015).
Dates are heterogeneous and considered a sugar rich fruit with low and intermediate moisture content (Assirey, 2015). The phase of water influences the characteristics of any fresh produce in both biochemical and microbial stabilities (Guizani et al. 2010). Freezing of food material involves numerous phenomena which provides more stable products (Giannakourou and Giannou, 2014). The freezing process is a combination of the beneficial effects of low temperatures and change of water from liquid to solid (Sablani, 2011; Bolnd and Le Meste, 2006). During the freezing process, as the temperature of food materials decreases, the viscosity increases. When the viscosity reaches $10^{12}-10^{14}$ Pa.s, solidification appears and the concentrated phase in the product turns into glass. The temperature at this transition is called the glass transition temperature (Rahman, 2004). Food products that have low moisture content such as dates are considered amorphous materials and exist as a viscous glass or as a liquid-like rubber (Ahmed et al., 2005). It is well recognized that food materials are very stable at its glassy state, where the

\footnotetext{
${ }^{*}$ Corresponding author:

Amr M. Zaitoon, Department of Agricultural and Bio-Systems Engineering, Faculty of Agriculture, Alexandria University, Egypt.

E-mail: amr.zaitoon@alexu.edu.eg
} 
compounds involved in deterioration reactions will be strongly limited below the glass transition temperature. (Guizani et al., 2010). Hence, many amorphous foods (i.e. dry dates) should be stored at its glass transition temperature to avert rapid deterioration and keep quality. (Roos, 2002; Slade and Levine, 1995). Shomer et al., 1998 reported that the tissues of Madjhoul date fruit (at $24 \%$ water content) stored at a temperature between 0 and $-18^{\circ} \mathrm{C}$ deteriorated during 10 months of preservation. However, Injuries and damages were not discovered in fruit tissues storage at lower temperatures between -35 and $-50^{\circ} \mathrm{C}$.

DSC is a thermo-analytical technique, which is used for determining the thermal transitions of food products. Also, it is the most used technique because of its unique characteristics, high precision, and simplicity. DSC determines the heat energy required and temperature changes between a sample and reference within a modified increase or decrease in temperature. (Syamaladevi, 2012). Some factors are affecting the calorimetric determination of the thermal properties of food such as heating rate and annealing condition employed during DSC scan, in addition to moisture content of the food material (Sunooj et al., 2009). Studies on the thermal properties of dates are very limited. Rahman, (2004) and Guizani et al. (2010) developed the state diagram of dates by determining its initial freezing points, glass transition temperatures, and solute melting points. Ahmed et al., (2005) studied the glass transitions of date pastes as affected by water activity. Also, Elansari, (2015) investigated the thermal properties of three varieties of date's cultivars at two stages of maturity, which are khalal and rutab stage.

The objective of this work was to study the effect of three variables on the glass transition of Samani dates and they are; heating rate, annealing condition, and moisture content.

\section{MATERIALS AND METHODS}

\section{Raw materials}

Samani date palm (Phoenix dactylifera 1.,) fruits were harvested at khalal and rutab stages from Idku city, Elbeheira governorate, Egypt. The fruits were sorted out to eliminate damaged fruits, and stored at $5{ }^{\circ} \mathrm{C}$ until used for a maximum period of three days. The length and diameter of dates were measured with a caliper and they were $5.55 \pm 0.07$, and $3.49 \pm 0.04 \mathrm{~cm}$, respectively. The mass of the fruit was measured using a calibrated digital balance (Vibra CG-1500, Japan) and it was 34.92 $\pm 0.89 \mathrm{~g}$. The fruit color was measured using the Minolta colorimeter (Minolta, Chroma Meter CR-200) and L*, a* and $\mathrm{b}^{*}$ color space were $60.28 \pm 2.03,22.35 \pm 2.22$, and $24.97 \pm 2.19$, respectively.

\section{Chemical composition}

The chemical composition of Samani date fruit at khalal stage was determined. A sample of thirty fruits as uniform in size and color as possible, free from mechanical and external defects were selected to determine the chemical composition, where three replicate were used. The fruits of each replicate was pitted, cut into small pieces and mixed properly then used in the chemical analysis. The chemical parameters were Moisture content, total carbohydrates, protein, fat, crude fiber and ash. The moisture content was determined by drying the samples in the oven at $70^{\circ} \mathrm{C}$ until weight constant, then calculated by weight differences and expressed as percentage. Kjeldahl method was used to determine the total nitrogen using nitrogen distiller (Raypa, DNP-1500-MP) according to (AOAC, 2005). The total nitrogen was multiplyed by factor of 6.26 to calculate the protein content. Crude fat percentage was determined according to (AOAC, 2005), the fat was extracted with petroleum ether at 40 to $60^{\circ} \mathrm{C}$ in a fat analyzer (Ankom, $\mathrm{XT10}$ ) for $16 \mathrm{~h}$. Crude fiber was determined using fiber analyzer at $105^{\circ} \mathrm{C}$ after the digesting with $\mathrm{H}_{2} \mathrm{SO}_{4}$ and $\mathrm{NaOH}$. To determine the total ash content, samples were incinerated in a muffle furnace (HD 230PA, Spain) at $550^{\circ} \mathrm{C}$ to a constant weight. Total carbohydrates were determined by calculating the percentage remaining after all the other components have been measured.

\section{Samples preparation}

The date samples for the determination of thermal transitions were prepared with a small knife and forceps to get a thin slice of the date flesh. Samples of (5-10 mg) were put in pre-weighted aluminum pans (Aluminum pan $ø 6, \mathrm{P} / \mathrm{N}$ : 201-52943) using auto-calibrated digital balance (Model CX301, Citizen, USA). Then pans were hermetically sealed using sample sealer (SSC-30, P/N: 201-52000-90). Samples were prepared just before analysis to avoid any physical or chemical changes within the date flesh and then put into the instrument at the lab temperature along with an empty pan as reference and then scanned at heating rate 1,5 , or $10^{\circ} \mathrm{C} / \mathrm{min}$ by the DSC.

For studying heating rate and annealing conditions effects, Samani dates, at khalal stage, with constant moisture content of $67.22 \%$ (w.b) were used. Samani date at rutab stage with three different moisture levels was used to study the effect of moisture content. The moisture content of Samani at rutab stage was $51.2 \%$ and was decreased to $38.5 \%$ and $30.4 \%$ using drying oven (Fisher, 200 Series, Model 230G) at $70{ }^{\circ} \mathrm{C}$. All samples were stored in air-sealed glass jars at $-18^{\circ} \mathrm{C}$ until used.

\section{Differential scanning calorimeter (DSC)}

Glass transition temperature $\left(\mathrm{T}_{\mathrm{q}}\right)$, onset of melting point $\left(\mathrm{T}_{\mathrm{m}}\right)$, initial freezing point $\left(\mathrm{T}_{\mathrm{F}}^{\mathrm{g}}\right)$, and enthalpy change 
during melting $\left(\mathrm{H}_{\mathrm{m}}\right)$ of Samani dates were measured by Differential Scanning Calorimeter (DSC-60A, Shimadzu, Japan). Liquid nitrogen was used to cool the sample to $-90{ }^{\circ} \mathrm{C}$. Nitrogen gas with flow rate $50 \mathrm{~mL} / \mathrm{min}$ was used to eliminate water condensation in the measuring cell and prevent dew/frost formation. The instrument calibration was done using zinc [melting point $=419.5^{\circ} \mathrm{C}$; $\Delta \mathrm{H}_{\mathrm{m}}=113.27 \mathrm{~J} / \mathrm{g}$ ] and indium [melting point $=156.5^{\circ} \mathrm{C}$; $\left.\Delta \mathrm{H}_{\mathrm{m}}=28.5 \mathrm{~J} / \mathrm{g}\right]$.

\section{Scanning procedures}

For non-annealing trails; date samples were cooled to $-90^{\circ} \mathrm{C}$, at a cooling rate of $20^{\circ} \mathrm{C} / \mathrm{min}$, and equilibrated for $10 \mathrm{~min}$. Then, it was heated from -90 to $50^{\circ} \mathrm{C}$, at heating rate 1 , 5 or $10{ }^{\circ} \mathrm{C} / \mathrm{min}$. Each thermogram profile was tested for the onset, mid, and end of glass transition temperature $\left(\mathrm{T}_{\mathrm{gi}}\right.$, $\mathrm{T}_{\mathrm{gp}}$, and $\mathrm{T}_{\mathrm{ge}}$, and for melting characteristic.

For annealing trails; samples were annealed at $-30{ }^{\circ} \mathrm{C}$ for $30 \mathrm{~min}$. The procedures was as follows: Cooling to $-80^{\circ} \mathrm{C}$ at $20^{\circ} \mathrm{C} / \mathrm{min}$, heating at 1,5 , or $10^{\circ} \mathrm{C} / \mathrm{min}$ to $-30^{\circ} \mathrm{C}$, annealing for $30 \mathrm{~min}$ at $-30^{\circ} \mathrm{C}$, cooling at $20^{\circ} \mathrm{C} / \mathrm{min}$ to $-80^{\circ} \mathrm{C}$, then heating from $-80^{\circ} \mathrm{C}$ to $50^{\circ} \mathrm{C}$ at 1,5 , or $10^{\circ} \mathrm{C} / \mathrm{min}$.

The onset of $\mathrm{T}_{\mathrm{gi}}$ and end $\mathrm{T}_{\mathrm{ge}}$ points of transitions were obtained by extrapolating the side and base lines. The peak temperature of the melting endotherm was taken as $T_{F}$ The intersection point of the baseline with the left side of the melting endotherm was taken as $\mathrm{T}_{\mathrm{m}}$. $\mathrm{H}_{\mathrm{m}}$ was estimated from the area of the ice melting endotherm (Rahman, et al., 2008; Syamaladevi, 2012).

\section{Statistical analysis}

The DSC measurements were done in triplicate and data were shown as mean \pm standard deviation. Statistical analysis was performed using SAS 9.1.3 software. Analysis of variance (ANOVA) according to (Petersen, 1985) was used with $\mathrm{p}<0.05$. The differences among the means were determined for significance at $\mathrm{p}<0.05$ using Duncan multiple range test (DMRT 0.05).

\section{RESULTS AND DISCUSSION}

\section{Chemical composition}

The average proximate composition of Samani date flesh at khalal stage was determined. Moisture content was the predominant component with value of $67.22 \pm 0.05 \%$ followed by Carbohydrate with value of $25.72 \pm 0.01 \%$, along with small amounts of crude fiber, protein, ash, and fat with values of $3.71 \pm 0.02 \%, 2.11 \pm 0.06 \%$, $0.86 \pm 0.01 \%$, and $0.37 \pm 0.03 \%$, respectively. These measurements were taken to identify the quality of the fruits under study.

\section{DSC thermograms}

The DSC scans for Samani date sample was a curve represents the relationship between the heat flow $(\mathrm{mW})$ versus temperature $\left({ }^{\circ} \mathrm{C}\right)$, in which it is called thermogram or heat flow curve. A DSC thermogram of Samani date is shown in Fig. 1 and shows the cooling curve of Samani date sample from ambient temperature to $-90{ }^{\circ} \mathrm{C}$ which exhibit freezing of water during cooling (exothermic peak). Also, it shows the heating curve of the sample from $-90{ }^{\circ} \mathrm{C}$ to $50^{\circ} \mathrm{C}$. The heating curve demonstrates a second-order glass transition which known from the step change in the heat flow, in addition melting of ice during heating (endothermic peak). Thermograms of Samani date were almost identical to that of food products with high moisture content, which exist in published literature (Hobani and Elansari, 2004; Rahman, 2004; Guizani, et al., 2010).

The onset, mid, and end of glass transition temperature $\left(\mathrm{T}_{\mathrm{gi}}, \mathrm{T}_{\mathrm{gp}}\right.$, and $\left.\mathrm{T}_{\mathrm{ge}}\right), \mathrm{T}_{\mathrm{m}}, \mathrm{T}_{\mathrm{p}}$ and $\mathrm{H}_{\mathrm{m}}$ were obtained from the analysis of thermograms as shown in Fig. 2. It is better to analyze the DSC heating curve rather than the cooling curve to determine the thermal transitions, (Rahman, et al., 2008).

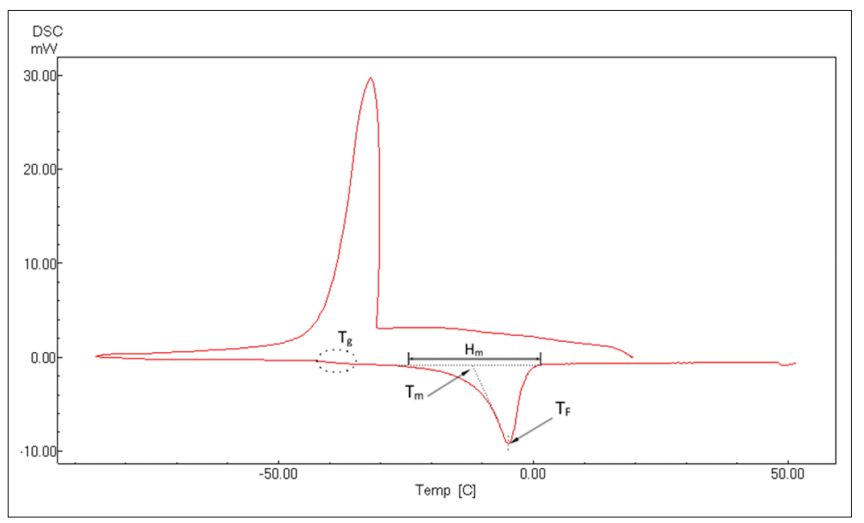

Fig 1. A typical DSC thermogram for Samani date at khalal stage (M.C $=67.22 \%$ ) scanned at heating rate $10^{\circ} \mathrm{C} / \mathrm{min}$ without annealing showing freezing of water during cooling (exotherm) and melting of ice during heating (endotherm), in addition to glass transition.

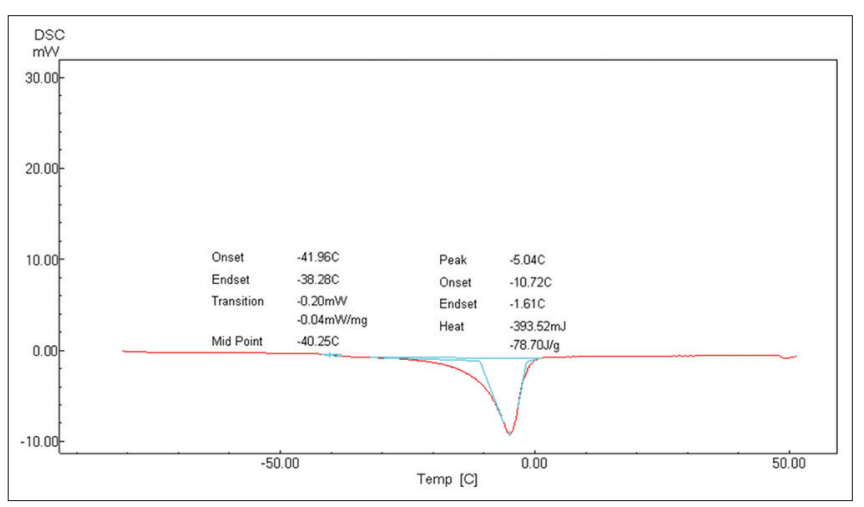

Fig 2. The analysis of the DSC thermogram of Samani date at khalal stage $(M . C=67.22 \%)$ scanned at heating rate $10{ }^{\circ} \mathrm{C} / \mathrm{min}$ without annealing showing glass transition and endotherm peak of melting. 


\section{Glass transition}

The glass transition is the temperature region where the phase of amorphous materials change from the glassy to the rubbery state upon heating, or vice versa if cooled (Foreman et al., 2013). Glass transition often occur during a temperature range instead of a single temperature (Le Meste et al., 2002). Also, the onset temperature of glass transition $\left(\mathrm{T}_{\mathrm{g} i}\right)$ is more important than the end temperature $\left(\mathrm{T}_{\mathrm{ge}}\right)$, where the properties of food material changes dramatically over the onset temperature (Roos, 2007).

\section{Effect of heating rate and annealing on $T_{g}$}

The glass transition temperatures $\left(\mathrm{T}_{\mathrm{g}}, \mathrm{T}_{\mathrm{gp}}\right.$, and $\left.\mathrm{T}_{\mathrm{ge}}^{\mathrm{g}}\right)$ of Samani date at khalal stage scanned at different heating rates were summarized in Table 1. The midpoint of glass transition $\mathrm{T}_{\mathrm{gp}}$ was $-41.58,-40.70$, and $-39.31^{\circ} \mathrm{C}$ at 1,5 , and $10^{\circ} \mathrm{C} / \mathrm{min}$ heating rate without annealing, while it was $-38.51,-37.59$, and $-36.17^{\circ} \mathrm{C}$ at the mentioned heating rate with annealing, respectively. These results showed that as the heating rate increases, the $\mathrm{T}_{\mathrm{gp}}$ increases significantly $(\mathrm{p}<0.05)$. The same trend was observed also for $\mathrm{T}_{\text {gi }}$; and $\mathrm{T}_{\mathrm{ge}}$. Fig. 3 depicts the variation of glass transition temperature $\mathrm{T}_{\mathrm{gp}}$ for the samples with different heating rates. Similar results have been earlier reported by Rahman, (2004), Liu et al., (2009), and Sunooj et al., (2009) where they reported that as heating rate increases, the glass transition temperature tends to have higher values. Also, Ozmen, (2002) documented that when heating rate was changed from $10{ }^{\circ} \mathrm{C} / \mathrm{min}$ to $2{ }^{\circ} \mathrm{C} / \mathrm{min}$, the glass transition temperature decreased significantly by $4.1^{\circ} \mathrm{C}$. Thomas, (2001) reported that two factors are responsible for the increase of glass transition temperature with heating rate: 1) The low thermal conductivity of the sample therefore the temperature of the center lags the temperature of the surface and 2) the molecular mobility change which is associated with glass transition and has a weak kinetic contribution.

Annealing has a significant $(\mathrm{p}<0.05)$ effect on glass transition temperatures, where $\mathrm{T}_{\mathrm{g}} ; \mathrm{T}_{\mathrm{gp}}$; and $\mathrm{T}_{\mathrm{ge}}$ for annealed trails was higher than it for non-annealed ones. The same observation was mentioned by Sa et al., (1999) and Bai et al., (2001) while studying the glass transition temperature of apple slices. They demonstrated that isothermal annealing led to increased glass transition values, but the opposite was found by Shi et al., (2012) for glass transition temperature of Agaricus bisporus samples. Since our product was much similar to apple, where both of them considered as fruit with high sugars and moisture content, the results of the current study confirms the first suggestion.

\section{Effect of moisture content on $\mathrm{T}_{\mathrm{g}}$}

Date samples with different moisture levels were used to study the effect of moisture content on the glass transition temperatures. DSC scans were conducted at $5{ }^{\circ} \mathrm{C} / \mathrm{min}$ heating rate without annealing. The obtained glass transition temperatures were outlined in Table 2. $\mathrm{T}_{\mathrm{gi}} ; \mathrm{T}_{\mathrm{gp}}$; and $\mathrm{T}_{\mathrm{ge}}$ decreased significantly $(\mathrm{p}<0.05)$ from -43.02 to -54.64 ; -41.95 to -53.64 ; and -40.27 to $-51.65{ }^{\circ} \mathrm{C}$ as moisture content of date flesh increased from 30.4 to $51.2 \%$, respectively. Fig. 4 shows the effect of moisture content on $\mathrm{T}_{\mathrm{g}}$ values at rutab stage. The glass transition temperatures for at khalal stage were higher than at rutab stage scanned at the same heating rate, although Samani at khalal stage has much higher moisture content. This could be due to the change in chemical composition during ripping of date and the transformation of sugars from sucrose to glucose and fructose (Ahmed, 2011). The same results were observed by Elansari, (2015) while determining the glass transition temperature of Berhi,

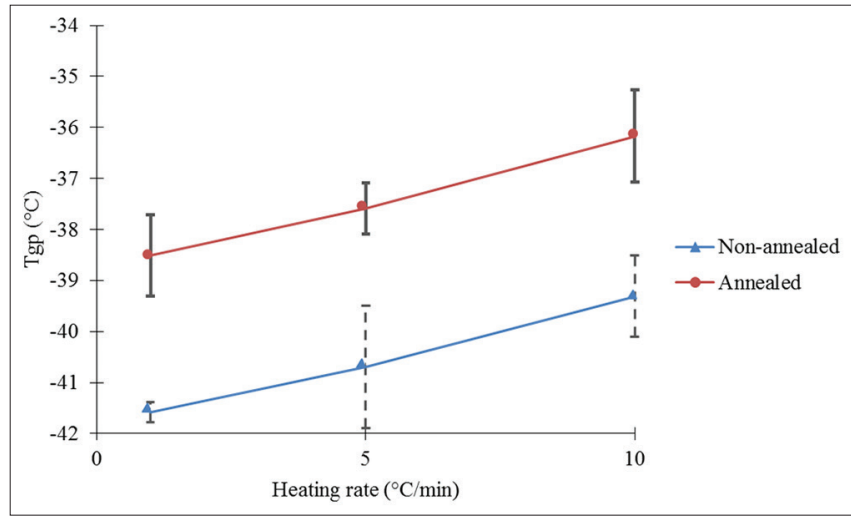

Fig 3. Effect of heating rate on the midpoint of glass transition for Samani date at khalal stage (M.C $=67.22 \%$ ).

Table 1: Thermal properties of Samani date flesh at khalal stage with moisture content of $67.22 \%$ as affected by heating rate with/ without annealing

\begin{tabular}{|c|c|c|c|c|c|c|}
\hline Rate $\left({ }^{\circ} \mathrm{C} / \mathrm{min}\right)$ & $\mathrm{T}_{\mathrm{gi}}\left({ }^{\circ} \mathrm{C}\right)$ & $\mathrm{T}_{\mathrm{qp}}\left({ }^{\circ} \mathrm{C}\right)$ & $\mathrm{T}_{\mathrm{ge}}\left({ }^{\circ} \mathrm{C}\right)$ & $\mathrm{T}_{\mathrm{m}}\left({ }^{\circ} \mathrm{C}\right)$ & $\mathrm{T}_{\mathrm{F}}\left({ }^{\circ} \mathrm{C}\right)$ & $H_{m}(K J / K g)$ \\
\hline \multicolumn{7}{|l|}{ Non-annealing } \\
\hline 1 & $-42.96 \pm 0.3 a$ & $-41.58 \pm 0.2 a$ & $-40.52 \pm 0.4 a$ & $-7.06 \pm 0.7 a$ & $-3.95 \pm 0.7 a$ & $81.75 \pm 3.0 a$ \\
\hline 5 & $-42.42 \pm 1.3 a$ & $-40.7 \pm 1.2 \mathrm{ab}$ & $-38.87 \pm 1.8 a b$ & $-8.59 \pm 1 a b$ & $-4.25 \pm 0.8 a$ & $80.08 \pm 4.0 \mathrm{a}$ \\
\hline 10 & $-40.97 \pm 0.9 a$ & $-39.31 \pm 0.8 b$ & $-37.38 \pm 0.8 b$ & $-9.87 \pm 0.8 b$ & $-4.54 \pm 0.5 a$ & $79.16 \pm 4.6 \mathrm{a}$ \\
\hline \multicolumn{7}{|l|}{ Annealing } \\
\hline 1 & $-39.60 \pm 1.6 a$ & $-38.51 \pm 0.8 a$ & $-36.32 \pm 1.3 a$ & $-8.34 \pm 0.2 a$ & $-4.56 \pm 0.1 a$ & $96.51 \pm 1 . a$ \\
\hline 5 & $-39.47 \pm 0.6 a$ & $-37.59 \pm 0.5 a b$ & $-36.02 \pm 0.8 a$ & $-8.49 \pm 0.2 a$ & $-4.15 \pm 0.3 a$ & $95.24 \pm 1.2 \mathrm{a}$ \\
\hline 10 & $-38.80 \pm 0.5 a$ & $-36.17 \pm 0.9 b$ & $-33.54 \pm 0.8 b$ & $-8.51 \pm 0.1 a$ & $-3.40 \pm 0.6 a$ & $94.93 \pm 2.1 \mathrm{a}$ \\
\hline
\end{tabular}


Table 2: Thermal properties of Samani date flesh at rutab stage scanned at heating rate $5^{\circ} \mathrm{C} / \mathrm{min}$ without annealing as affected by moisture content

\begin{tabular}{|c|c|c|c|c|c|c|}
\hline M.C \% & $\mathrm{T}_{\mathrm{qi}}\left({ }^{\circ} \mathrm{C}\right)$ & $\mathrm{T}_{\mathrm{qp}}\left({ }^{\circ} \mathrm{C}\right)$ & $\mathrm{T}_{\mathrm{qe}}\left({ }^{\circ} \mathrm{C}\right)$ & $\mathrm{T}_{\mathrm{m}}\left({ }^{\circ} \mathrm{C}\right)$ & $\mathrm{T}_{\mathrm{F}}\left({ }^{\circ} \mathrm{C}\right)$ & $\mathrm{H}_{\mathrm{m}}(\mathrm{KJ} / \mathrm{Kg})$ \\
\hline 30.4 & $-43.02 \pm 0.3 a$ & $-41.95 \pm 0.8 a$ & $-40.27 \pm 0.9 a$ & $-31.05 \pm 0.2 a$ & $-22.94 \pm 0.2 a$ & $0.92 \pm 0.1 a$ \\
\hline 38.5 & $-49.26 \pm 0.4 b$ & $-47.69 \pm 0.8 b$ & $-45.87 \pm 0.9 b$ & $-27.94 \pm 0.6 b$ & $-18.84 \pm 0.6 b$ & $42.84 \pm 1.2 b$ \\
\hline 51.2 & $-54.64 \pm 0.1 c$ & $-53.17 \pm 0.1 c$ & $-51.65 \pm 0.2 c$ & $-19.17 \pm 0.7 c$ & $-11.63 \pm 0.2 c$ & $73.48 \pm 2.8 \mathrm{c}$ \\
\hline
\end{tabular}

Values are mean \pm standard deviation. Values with the same letters in the same column for each group are not significantly different at 0.05

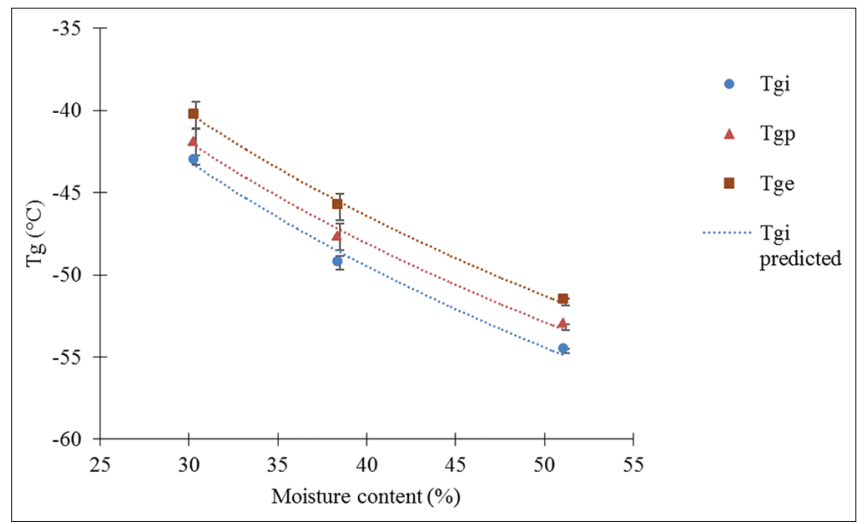

Fig 4. Effect of moisture content on the glass transition temperatures for Samani date at rutab stage scanned at $5{ }^{\circ} \mathrm{C} / \mathrm{min}$ without annealing.

Helwa and Meggei dates at two stages of maturity, which were khalal and rutab. The above results were in line with those found by Rahman, (2004), and Guizani et al., (2010) in case of studying the glass transition of different date varieties. Also, Ahmed et al., (2005) obtained the same results while studying the glass transition of khalas date pastes. Syamaladevi, (2012) reported that glass transition temperatures of high moisture food products have a little change when water content is increased, while the opposite is found in dry and semi-dry food products.

The effect of moisture content on glass transition temperature is attributed to the low glass transition temperature of water which is about $-135{ }^{\circ} \mathrm{C}$ (Johari et al., 1987) and the plasticization effect of water due to its low molecular weight (Tolstoguzov, 2000).

\section{Thermal properties}

Among the thermal properties of Samani dates are; onset of melting point $\left(\mathrm{T}_{\mathrm{m}}\right)$, initial freezing point $\left(\mathrm{T}_{\mathrm{F}}\right)$, and enthalpy change during melting $\left(\mathrm{H}_{\mathrm{m}}\right)$. These properties were determined from the analysis of DSC heating curves as shown in Fig. 2. The influence of heating rate and annealing condition on the thermal properties at khalal stage was outlined in Table 1, while Table 2 shows the effect of moisture content on thermal properties at rutab stage.

\section{Effect of heating rate and annealing on the thermal properties}

Onset of melting point, $\mathrm{T}_{\mathrm{m}}$ value was decreased with increasing heating rate, where it was $-7.06,-8.59$, and $-9.87^{\circ} \mathrm{C}$ at heating rate $1,5,10^{\circ} \mathrm{C} / \mathrm{min}$ without annealing, respectively. The same trend was observed for annealing trails where it was $-8.34,-8.49$, and $-8.51{ }^{\circ} \mathrm{C}$ at the same heating rate, respectively, (Table 1). Also, $\mathrm{T}_{\mathrm{F}}$ value was decreased with the increase of heating rate for nonannealing trails, but for annealing trails it was increased. $\mathrm{T}_{\mathrm{F}}$ value was $-3.95,-4.25$, and $-4.54{ }^{\circ} \mathrm{C}$ for non-annealing trails and $-4.56,-4.15,-3.40{ }^{\circ} \mathrm{C}$ for annealing trails at 1,5 , $10^{\circ} \mathrm{C} / \mathrm{min}$ heating rate, respectively. $\mathrm{T}_{\mathrm{m}}$ and $\mathrm{T}_{\mathrm{F}}$ for annealed samples was higher than it for non-annealed ones at rate 5 and $10{ }^{\circ} \mathrm{C} / \mathrm{min}$ but the opposite was observed at rate $1{ }^{\circ} \mathrm{C} / \mathrm{min}$ with no significant differences. $\mathrm{H}_{\mathrm{m}}$ shifted to slightly higher value as the heating rate decreased, where it was $81.75,80.08$, and $79.16 \mathrm{~kJ} / \mathrm{kg}$ without annealing, while it was $96.51,95.24$, and $94.93 \mathrm{~kJ} / \mathrm{kg}$ with annealing, at $1,5,10^{\circ} \mathrm{C} / \mathrm{min}$ heating rate, respectively. Also, $\mathrm{H}_{\mathrm{m}}$ for annealed trails was much higher than that for nonannealed ones since annealing allows to form the largest amount of ice. Statistical analysis showed that the heating rate has a significant $(\mathrm{p}<0.05)$ effect on $\mathrm{T}_{\mathrm{m}}$ values and has no significant effect on $\mathrm{T}_{\mathrm{F}}, \mathrm{H}_{\mathrm{m}}$ values. Also, annealing has significant effect on $\mathrm{H}_{\mathrm{m}}$ and has no significant effect on $\mathrm{T}_{\mathrm{m}}$ and $\mathrm{T}_{\mathrm{F}}$ values. Figs. 5-7 depict the effect of heating rate and annealing on the thermal properties of Samani date at khalal satge.

A few published literatures studied the effect of heating rate and annealing on the thermal properties of food materials. Especially for dates or similar fruit, there is no published literatures concerning these effects. However, Sablani et al., (2007) reported that as heating rate increases, $\mathrm{T}_{\mathrm{F}}$ and $\mathrm{T}_{\mathrm{m}}$ increases, during their study of the thermal transitions of the king fish. Suresh et al., (2013) found that the melting peak temperature of date-pits powder increases exponentially and the enthalpy change during melting decreases with increasing heating rate. The peak temperature increases exponentially when samples were annealed close to the onset of ice melting point, also the enthalpy change during melting decreases with the increase of annealing time. Bai et al., (2001) reported that isothermal holding (annealing) led to increase $\mathrm{T}_{\mathrm{m}}, \mathrm{T}_{\mathrm{F}}$ and $\mathrm{H}_{\mathrm{m}}$ values. Sunooj et al., (2009) documented that annealing temperature affect $\mathrm{H}_{\mathrm{m}}$ values significantly, where it increases with annealing temperature.

Effect of moisture content on the thermal properties The thermal properties; $T_{m}, T_{F}$ and $H_{m}$ have a significant $(\mathrm{p}<0.05)$ increased with increasing moisture content as 


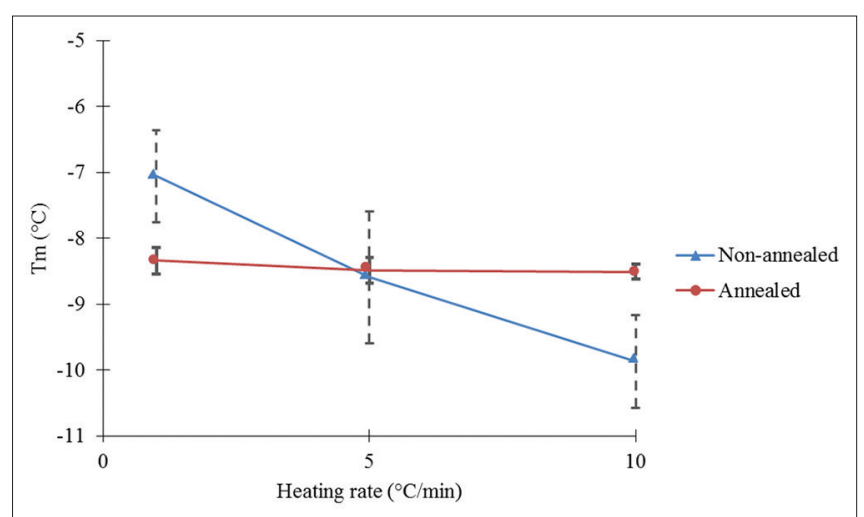

Fig 5. Effect of heating rate on the onset melting point for Samani date at khalal stage (M.C $=67.22 \%)$.

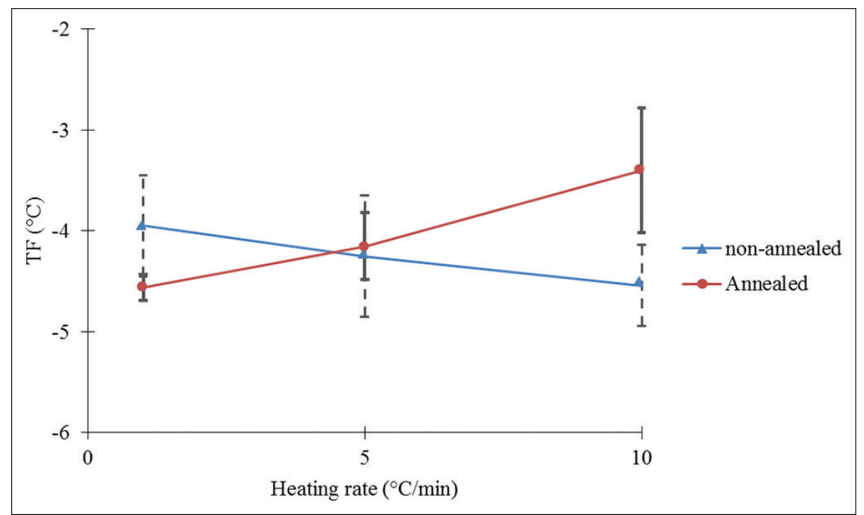

Fig 6. Effect of heating rate on the initial freezing point for Samani date at khalal stage (M.C $=67.22 \%)$.

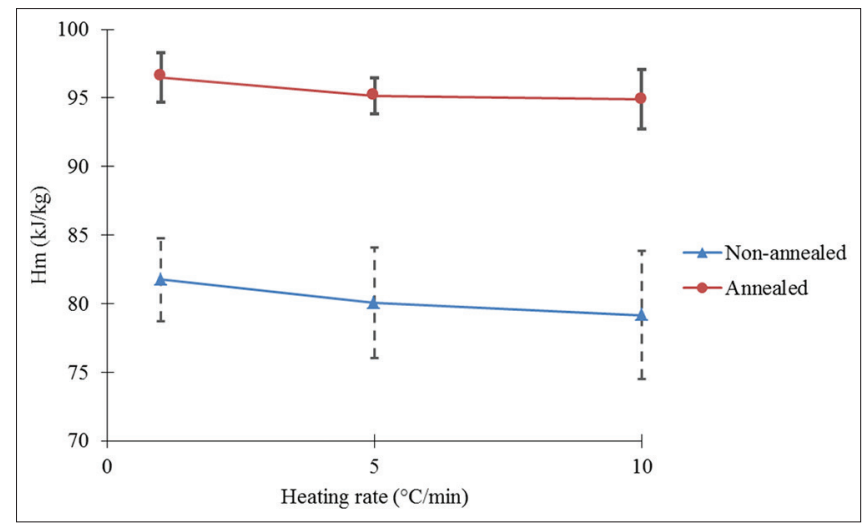

Fig 7. Effect of heating rate on the latent heat of melting for Samani date at khalal stage $($ M.C $=67.22 \%)$.

shown in Table 2, where $\mathrm{T}_{\mathrm{m}}$ value varied from -31.05 to $-19.17^{\circ} \mathrm{C}$, and $\mathrm{T}_{\mathrm{F}}$ value varied from -22.94 to $-11.63{ }^{\circ} \mathrm{C}$, and $\mathrm{H}_{\mathrm{m}}$ value varied from 0.915 to $73.48 \mathrm{~kJ} / \mathrm{kg}$, when moisture content changed from 30.4 to $51.2 \%$, respectively. Figs. 8-10 depict the effect moisture content on the thermal properties at rutab satge. Dates are heterogeneous, in which they consist of minerals and organic component, such as sugars, fats, proteins, fiber, and acids, in addition to water, which is considered the major component of dates along

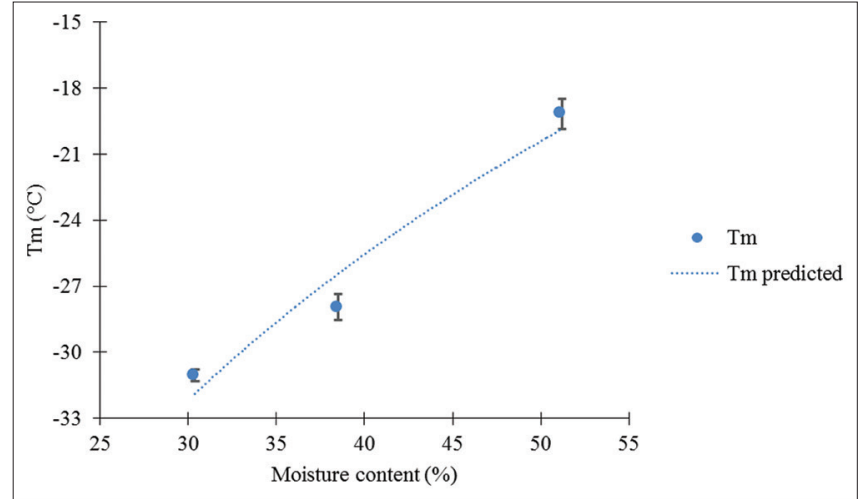

Fig 8. Effect of moisture content on the onset melting point for Samani date at rutab stage scanned at $5^{\circ} \mathrm{C} / \mathrm{min}$ without annealing.

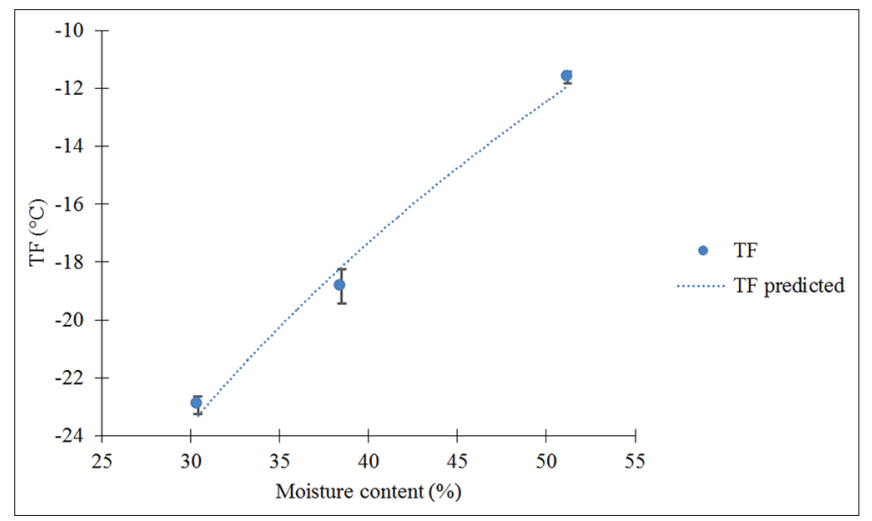

Fig 9. Effect of moisture content on the initial freezing point for Samani date at rutab stage scanned at $5{ }^{\circ} \mathrm{C} / \mathrm{min}$ without annealing.

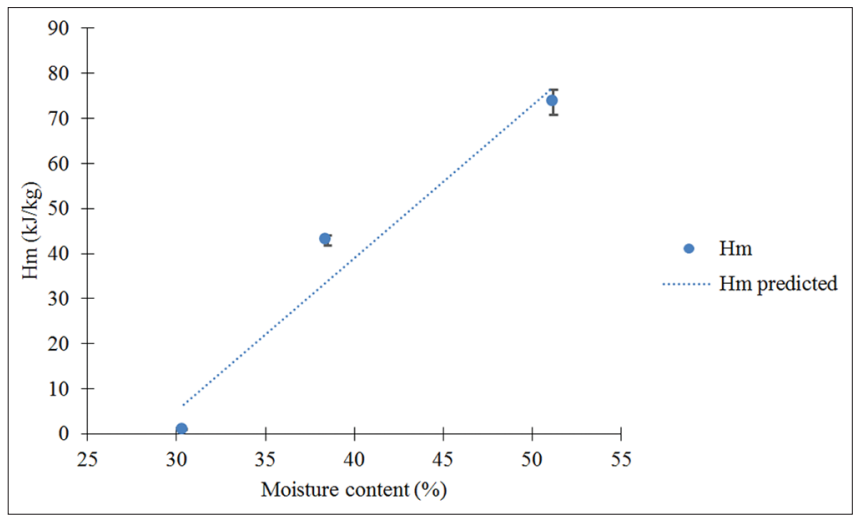

Fig 10. Effect of moisture content on the latent heat of melting for Samani date at rutab stage scanned at $5{ }^{\circ} \mathrm{C} / \mathrm{min}$ without annealing, showing the amount of un-freezable water.

with sugars (Ahmed et al., 2014), therefore the freezing point of date is lower than that of pure water and this depression is a result of the date constituents. The above results were in harmony with Rahman, (2004) who studied the effect of moisture content on thermal properties of khalas dates. He found that $\mathrm{T}_{\mathrm{m}}, \mathrm{T}_{\mathrm{F}}$ and $\mathrm{H}_{\mathrm{m}}$ decrease with increasing solids content (or with the decrease of moisture content). Same result was obtained also by Bai et al., (2001), Guizani et al., (2010), Shi et al., (2012), and Guizani et al., (2013). Borde 
et al., (2002) reported that enthalpy increases with increasing moisture content is attributed to the higher density of the hydrogen bond or the transformation in the solids-matrix.

The enthalpy change during melting $\left(\mathrm{H}_{\mathrm{m}}\right)$ was plotted against moisture content $(X)$ to determine un-freezable water quantity as shown in Fig. 10. A linear regression analysis was conducted and led to the following relationship:

$\mathrm{H}_{\mathrm{m}}=3.39 * \mathrm{X}-96.77$

Eq. 1 can be used to predict $\mathrm{H}_{\mathrm{m}}$ with determination coefficient $\mathrm{R}^{2}=0.953$. The amount of un-freezable water for Samani at rutab stage obtained by extrapoling the enthalpy line to $\mathrm{H}_{\mathrm{m}}$ equal to zero was $28.5 \%$ or $0.285 \mathrm{~g}$ water/g date flesh. This value is close to that recorded by Rahman, (2004) for khalas dates (0.32 g water/g date flesh). Also, Guizani et al., (2010) found that the amount of unfreezable water for Deglet Nour dates was $0.18 \mathrm{~g}$ water $/ \mathrm{g}$ date flesh. The quantity of un-freezable water observed for mango, raspberry, pineapple and fish muscle were 0.16, $0.16,0.27$, and $0.367 \mathrm{~g}$ water/g sample, respectively (Zhao et al., 2015; Syamaladevi, 2012; Telis and Sobral, 2001; and Sablani et al., 2007). The unfreezable water in frozen food which consist of non-crystallized water and bound water is defined as the quality of water that remains unfrozen at very low temperatures. (Xu et al., 2014). It is well known that the molecular mobility of unfrozen water in food products might result in deterioration during storage for long periods (Syamaladevi, 2012).

\section{CONCLUSIONS}

Various factors such as heating rate, annealing condition, and moisture content influencing the calorimetric determination of the $\mathrm{T}_{\mathrm{g}}, \mathrm{T}_{\mathrm{m}}, \mathrm{T}_{\mathrm{F}}$ and $\mathrm{H}_{\mathrm{m}}$ of dates. As heating rate decreases, the sensitivity increases. Since there is on significant differences between heating rate 1 and $5{ }^{\circ} \mathrm{C} / \mathrm{min}$, each of them can be used to determine the thermal transition of dates accurately, while moisture content should be evaluated correctly during the determination of the thermal properties of dates. Annealing at different temperatures and times should be studied to determine the optimum annealing conditions. Finally, these results can be used to enhance stability of stored dates, maintain quality, and extend shelf life. Also, it helps in framing a DSC protocol for determining phase transition information for dates using DSC.

\section{Authors' contributions}

Study concept and management: A. E., A. Z. Conducted the experiments: A. Z., Y. A., N. T. Analysis and interpretation of data: A. Z., A. E. Drafting of manuscript: A. Z., Y. A. Critical revision: A. E.

\section{REFERENCES}

Ahmed, J., F. M. Al-Jasass and M. Siddiq. 2014. Date fruit composition and nutrition. In: Siddiq, M., S. M. Aleid and A. A. Kader, (Eds.), Dates: Postharvest Science, Processing Technology and Health Benefits, $1^{\text {st }}$ ed. John Wiley \& Sons, Ltd., West Sussex, UK. Pp. 261-280.

Ahmed, J., H. S. Ramaswamy and A. R. Khan. 2005. Effect of water activity on glass transitions of date pastes. J. Food Eng. 66: 253-258.

Ahmed, Y. S. M. 2011. Induction of Rutab Stage in Some Inedible Khalal Dates by Postharvest Temperature Management. Ph.D. Thesis, Faculty of Agriculture, Alexandria University, Egypt.

Aleid, S. M. 2012. Dates. In: M. Siddiq (Ed.), Tropical and Subtropical Fruits Postharvest Physiology, Processing and Packaging, Wiley-Blackwell Publishers, Ames, IA. Pp. 179-201.

Al-Khayri, J. M. and Y. Ibraheem. 2014. In vitro selection of abiotic stress tolerant date palm (Phoenix dactylifera L.): A review. Emirates J. Food Agric. 26(11): 921-933.

AOAC. 2005. Official Methods of Analysis of AOAC International. $18^{\text {th }}$ ed. Association of Official Analytical Chemists, Gaithersburg, Maryland, USA.

Assirey, E. A. 2015. Nutritional composition of fruit of 10 date palm (Phoenix dactylifera L.) cultivars grown in Saudi Arabia. J. Taibah Univ. Sci. 9: 75-79.

Ateeq, A., S. D. Sunil, S. K. Varun and M. K. Santosh. 2013. Phoenix dactylifera linn (Pind kharjura): A review. Int. J. Res. 4(3): 447-451.

Bai, Y., M. S. Rahman, M, C. O. Perera and B. Smith. 2001. State diagram of apple slices: Glass transition and freezing curves. Food Res. Int. 34: 89-95.

Biglari, F. 2009. Assessment of Antioxidant Potential of Date (Phoenix dactylifera) Fruits From Iran, Effect of Cold Storage and Addition to Minced Chicken Meat. M.Sc. Thesis, University of Sains, Malaysia.

Bolnd, G. and M. Le Meste. 2006. Principles of frozen storage. In: Y. H. Hui (Ed.), Handbook of Food Science, Technology, and Engineering. Vol. 149. CRC Press, Boca Raton, FL.

Borde, B., H. Bizot, G. Vigier and A. Buleon. 2002. Calorimetric analysis of the structural relaxation in partially hydrated amorphous polysaccharides. I. Glass transition and fragility. Carbohydr. Polym. 48: 83-96.

Elansari, A. M. 2015. Phase Transition of Date Palm using Modulated Differential Scanning Calorimetry (MDSC). Poster Presentation in IFT15. Chicago, IL. USA.

FAOSTAT Data. 2015. Available from: http://www.faostat3.fao.org/. [Last accessed on 2015 Sep 15].

Foreman, J., S. R. Sauerbrunn and C. L. Marcozzi. 2013. Exploring the sensitivity of thermal analysis techniques to the glass transition. TA Instruments, Inc., 109 Lukens Drive New Castle. DE 19720.

Giannakourou, M. and V. Giannou. 2014. Chilling and freezing. In: Varzakas, T. and C. Tzia, (Eds.), Food Engineering Handbook: Food Process Engineering, CRC Press, Boca Raton, FL. Pp. 319-370.

Guizani, N., G. Al-Saidi, M. Rahman, S. Bornaz and A. Al-Alawi. 2010. State diagram of dates: Glass transition, freezing curve and maximal-freeze-concentration condition. J. Food Eng. 99: 92-97.

Guizani, N., M. S. Rahman, M. Klibi, A. Al-Rawahi and S. Bornaz. 2013. Thermal characteristics of Agaricus bisporus mushroom: Freezing point, glass transition, and maximal-freezeconcentration condition. Int. Food Res. J. 20(4): 1945-1952. 
Haider, M. S., I. A. Khan, M. J. Jaskani, S. A. Naqvi and M. M. Khan. 2014. Biochemical attributes of dates at three maturation stages. Emirates J. Food Agric. 26(11): 953-962.

Hobani, A. I. and A. M. Elansari. 2004. Thermal transitions of pomegranate extracts using modulated differential scanning calorimeter (MDSC). Int. J. Food Prop. 7(3): 671-681.

Ismail, W. I. W., M. Radzi and F. M. Naim. 2013. Evaluation on the benefits of date palm (Phoenix dactylifera) to the brain. Altern. Integr. Med. 2(4): 100-115.

Johari, G. P., A. Hallbrucker and E. Mayer. 1987. The glass-liquid transition of hyper quenched water. Nature. 330: 552-553.

Le Meste, M., D. Champion, G. Roudaut, G. Blond and D. Simatos. 2002. Glass transition and food technology: A critical appraisal. J. Food Sci. 67: 2444-2458.

Liu, P., L. Yu, H. Liu, H. Chen and L. Li. 2009. Glass transition temperature of starch studied by a high-speed DSC. Carbohydr. Polym. 77: 250-253.

Manickavasagan, A., K. Ganeshmoorthy, M. R. Claereboudt, R. Al-Yahyai and L. Khriji. 2014. Non-destructive measurement of total soluble solid (TSS) content of dates using near infrared (NIR) imaging. Emirates J. Food Agric. 26(11): 970-976.

Ozmen, L. 2002. Experimental investigation of the wall deposition of food containing carbohydrates, in a Pilot Scale Spray Dryer. M. Sc. Thesis, Department of Chemical Engineering, The University of Sydney.

Petersen, R. G. 1985. Design and Analysis of Experiments, Marcel Dekker, New York.

Rahman, M. S. 2004. State diagram of date flesh using differential scanning calorimetry (DSC). Int. J. Food Prop. 7(3): 407-428.

Rahman, M. S., K. M. Machado-Velasco, M. E. Sosa-Morales and J. F. Velez-Ruiz. 2008. Freezing point: Measurement, data, and prediction. In: M. S. Rahman (Ed.), Food Properties Handbook, $2^{\text {nd }}$ ed. CRC Press, Taylor \&Francis Group, Boca Raton, FL, USA. Pp. 154-186.

Roos, Y. H. 2002. Thermal analysis, state transitions and food quality. J. Therm. Anal. Calorim. 71: 197-203.

Roos, Y. H. 2007. Phase transitions and transformations in food systems. In: Heldman, D. R. and D. B. Lund, (Eds.), Handbook of Food Engineering, $2^{\text {nd }}$ ed. CRC Press, Taylor \&Francis Group, Boca Raton, FL. Pp.310-360.

Sa, M. M., A. M. Figueiredo, A. M. Sereno. 1999. Glass transitions and state diagrams for fresh and processed apple. Thermochim. Acta. 329: 31=38.
Sablani, S. S. 2011. Glass transitions in frozen food systems. In freezing. In: D. W. Sun (Ed.), Handbook of Frozen Food Processing and Packaging, CRC Press, New York.

Sablani, S. S., M. S. Rahman, S. Al-Busaidi, N. Guizani, N. Al-Habsi and B. Soussi. 2007. Thermal transitions of king fish whole muscle, fat and fat-free muscle by differential scanning calorimetry. Thermochim. Acta. 462: 56-63.

Shi, Q., X. Wanga, Y. Zhao and Z. Fang. 2012. Glass transition and state diagram for freeze-dried Agaricus bisporus. J. Food Eng. 111: 667-674.

Shomer, I., H. Borochov-Neori, B. Luzki and U. Merin. 1998. Morphological, structural and membrane changes in frozen tissues of Madjhoul date (Phoenix dactylifera L.) fruits. Postharvest Biol. Technol. 14: 207-215.

Siddiq, M., S. M. Aleid and A. A. Kader. 2014. Dates: Postharvest Science, Processing Technology and Health Benefits, $1^{\text {st }}$ ed. John Wiley \& Sons, Ltd., Chichester.

Slade, L., H. Levine. 1995. Glass transitions and water-food structure interactions. Adv. Food Nutr. Res. 38: 103-269.

Sunooj, K. V., K. Radhakrishna, J. George and A. S. Bawa. 2009. Factors influencing the calorimetric determination of glass transition temperature in foods: A case study using chicken and mutton. J. Food Eng. 91: 347-352.

Suresh, S., N. Guizani, M. Al-Ruzeiki, A. Al-Hadhrami, H. Al-Dohani, I. Al-Kindi and M. S. Rahman. 2013. Thermal characteristics, chemical composition and polyphenol contents of date-pits powder. J. Food Eng. 119: 668-679.

Syamaladevi, R. M. 2012. Physicochemical stability of selected frozen and dehydrated foods: In relation to state/phase transitions. Ph.D. Thesis, Washington State University, Department of Biological Systems Engineering.

Telis, V. R. N. and P. J. A. Sobral. 2001. Glass transitions and state diagram for freeze-dried pineapple. LWT Food Sci. Technol. 34: 99-205.

Thomas, L. C. 2001. Use of multiple heating rate DSC and modulated temperature DSC to detect and analyze temperature-timedependent transitions in materials. Am. Lab. USA. 33: 26-29.

Tolstoguzov, V. B. 2000. The importance of glassy biopolymer components in food. Nahrung. 44(2): 76-84.

Xu, C., Y. Li and H. Yu. 2014. Effect of far-infrared drying on the water state and glass transition temperature in carrots. J. Food Eng. 136: $42-47$. 